a organización mundial de la salud ha definido el concepto de salud como "El estado completo del bienestar físico, mental, y social", la salud sexual y reproductiva está implícita en esta definición.

El hombre históricamente ha tenido como interés el disfrute pleno de la sexualidad reflejándose este interés en diversas culturas. Es por esto que también desde la antigüedad las enfermedades de trasmisión sexual han sido un problema de salud pública.

Las enfermedades de trasmisión sexual (ETS) se conocen como enfermedades venéreas en honor a la diosa romana Venus equivalente a la diosa griega Afrodita (amor, belleza) y su trasmisión debido al contacto sexual; vaginal, anal u oral. Todas las conductas sexuales que involucren contacto con otra persona o alguno de sus fluidos biológicos se considera factor de riesgo para las ETS.

En la actualidad las ETS representan un serio problema de salud pública en el mundo. La OMS estima que 900 mil personas se infectan diariamente y se registran 340 millones de casos nuevos de ETS cada año, la proporción de casos es mayor entre personas de 15 a 45 años siendo similar en ambos sexos, destacándose la sífilis, gonorrea y clamidiasis.

¿Que son enfermedades de transmisión sexual?

Son un conjunto de enfermedades producidas por más de 30 virus, bacterias y parásitos trasmitidos por contacto sexual, ocho de ellos están vinculados con enfermedades de alta incidencia mundial, siendo cuatro curables a saber: sífilis, gonorrea, clamidiasis y tricomoniasis. Las otras cuatro son la hepatitis $B$, virus del herpes simple (HSV), Sida (HIV) y el virus del papiloma humano; todas son infecciones virales incurables aunque existan tratamientos capaces de atenuar - modificar la sintomatología o la enfermedad.

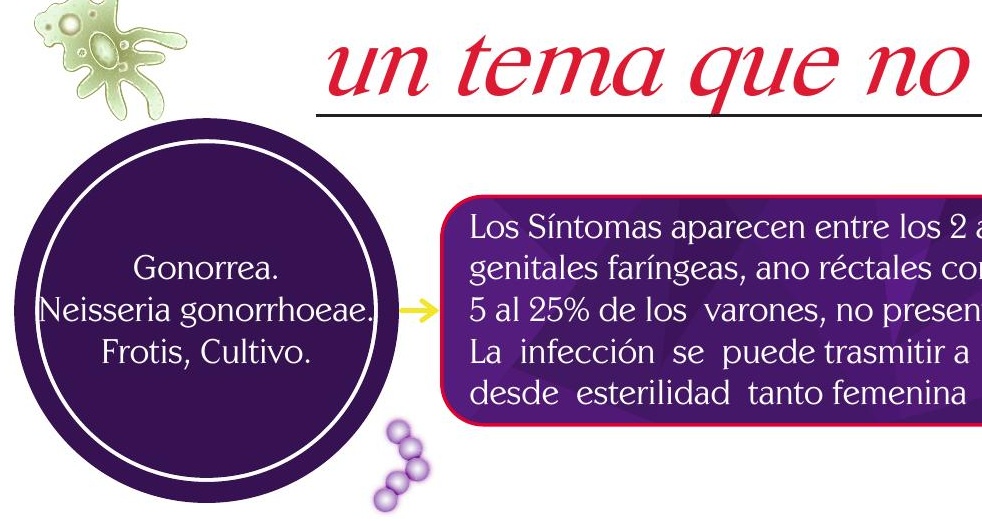

Trasmisión exclusiva por contacto directo, los primeros signos semana y los dos meses luego del contacto sospechoso. Aparec pene, genitales externos, paredes vaginales, ano o boca.

La infección puede trasmitirse a contactos sexuales. Sin tratan apareciendo años después como sífilis terciaria.

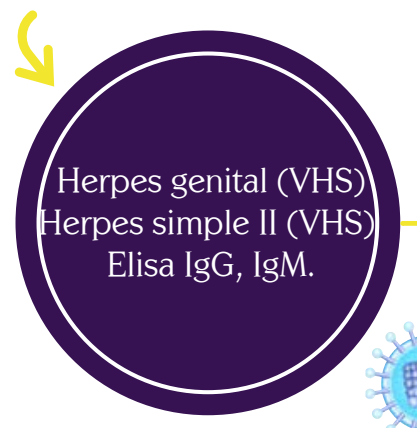

Entre 2 y 20 días luego del cont dolorosas variando su localización pudiendo producirse reinfecciones La infección se transmite a los cont
En la mayoría de los casos la infección es asintomática. Pue contacto sexual sospechoso. Son lesiones irregulares verrucosas Determinados tipos de virus VPD, se consideran precursores genitales externos. La infección puede trasmitirse a los contactos

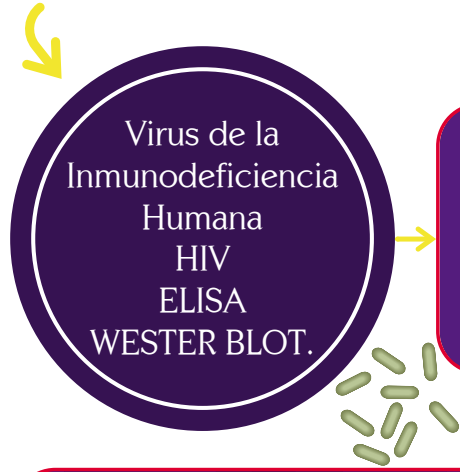

Produce el SIDA. Se transmite por pueden pasar 3 meses para que se puede no tener síntomas o dar un contactos sexuales. Sin tratamien encargado de la defensa apareci notablemente los periodos asinton

Generalmente cursa asintomática, si aparecen síntomas están en sexual sospechoso.

En el varón: Secreción uretral clara transparente, disuria.

En la mujer: aumentos del flujo sangrado tras la relación sexual. La infección se trasmite a los contactos sexuales. Puede causar pélvica, embarazos extra uterinos

Referencias:

1. Seminario "El ejercicio actual de la Medicina Enfermedac 2. Guía de prevención, diagnóstico, tratamiento de la ITS Fu 


\section{RANSMISIÓN SEXUAL}

pasa de MODA.

7 días después del contacto sospechoso. Producen infecciones n secreciones amarillentas. Más del $50 \%$ de las mujeres y entre el tan síntomas.

los contactos sexuales. Además puede producir complicaciones como masculina, o alteraciones en otros órganos

pueden aparecer entre la primera e una lesión "chancro primario" en hiento entra en periodo de latencia

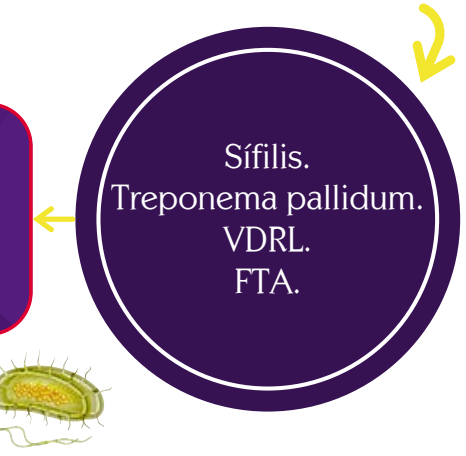

acto sexual, sospechoso aparecen ampollas pequeñas o ulceras según la práctica sexual. Luego de la lesión el virus queda latente actos sexuales este o no la infección activa.

den aparecer entre 1 y 20 meses del con aspecto de coliflor o aplanadas. del cáncer de cuello del útero o de sexuales.

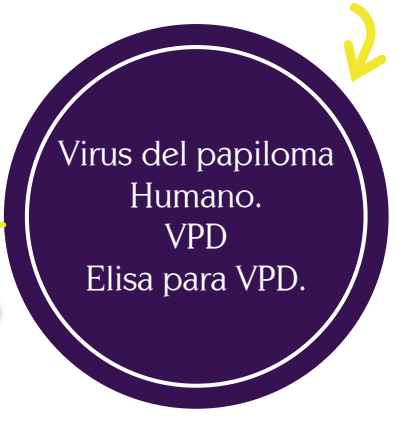

0008

vía parenteral, sexual o placentaria. Tras la práctica de riesgo pueda detectar los anticuerpos frente al HIV. La infección aguda cuadro semejante a una gripe. Las infecciones se trasmiten a los o producen un deterioro progresivo del sistema inmunitario endo infecciones oportunistas. Los tratamientos actuales alargan láticos.

tre los 7 y 21 días tras el contacto sterilidad enfermedad inflamatoria

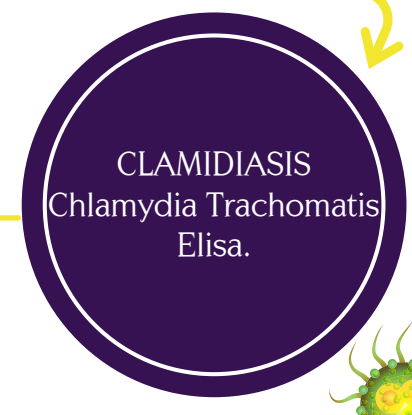

Por : Dr. Julio Mora C.

Facultad de Microbiología.

UCIMED.

\section{Medidas Preventivas}

El uso de preservativos (masculino o femenino) al tener relaciones sexuales.

Hablar con la pareja sexual acerca de su pasado sexual y del uso de drogas.

Muchas ETS incluido el VIH/SIDA no presentan signos externos de enfermedad por lo que es importante realizarse análisis periódicos.

Aprender a reconocer indicios, síntomas de una ETS. Si nota un síntoma que le preocupa acérquense al consultorio médico o el laboratorio para recibir información fidedigna.

Si tiene ETS, las personas que han tenido o tienen contactos sexual con usted es conveniente que acudan a un centro de salud (medico) o al laboratorio clínico (Microbiólogo) para recibir la información y el tratamiento adecuado.

\section{Tratamiento de la ETS}

Existe tratamiento eficaz para algunas ETS:

- Tres ETS bacterianas (clamidiasis, gonorrea y sífilis) y una parasitaria (tricomoniasis) son curables con terapias de antibióticos (dosis única) existentes.

- Herpes y HIV tienen medicamentos eficaces disponibles (antivíricos) que atenúan la evolución de la enfermedad sin curarla.

- Para la hepatitis B los moduladores del sistema inmunitario (interferón) y las medicamentos antivíricos ayudan contra el virus, y los daños hepáticos.

\section{El mejor tratamiento contra} ETS es la prevención. 